\title{
Primary Pulmonary Hypertension, Cerebrovascular Malformation, and Lymphoedema Feet in a Family
}

\author{
PRABHA AVASTHEY* AND SUJOY B. ROY \\ From the Department of Cardiology, All India Institute of Medical Sciences, New Delhi 16, India
}

Since Clarke et al. (1927) described primary pulmonary hypertension in two sisters, several families with more than one member involved have been reported (Lange, 1948; Dresdale, Michtom, and Schultz, 1954; van Epps, 1957; Coleman, Edmunds, and Tregillus, 1959; Fleming, 1960; Cahen et al., 1961 ; van Bogaert et al., 1961 ; Boiteau and Libanoff, 1963; Melmon and Braunwald, 1963; Parry and Verel, 1966; Kingdon et al., 1966). The present family is interesting because its several members suffered from more than one disease in common.

\section{CASE Reports}

The family first came under our observation in 1962. The grandparents were not known to have suffered from heart disease or lymphoedema. Sibs of the parents were described by them to be healthy. The family tree is shown in Fig. 1.

Case 1. This 38-year-old woman, the mother of the other patients to be described, had had two episodes of high fever, and redness and swelling over both feet and legs, at the ages of 13 and 15 years, respectively. Both attacks lasted two days each. Ever since then she had noticed swelling over both feet. Physical examination showed her to be a healthy-looking woman with nonpitting oedema over both feet and some pitting oedema over the shins. There was no clubbing or cyanosis. Peripheral pulses were normal. A loud systolic bruit was audible over both temporal regions of the skull and was conducted down the carotids. Fundi and the central nervous system were normal. Cardiovascular and respiratory systems and abdomen were normal. Skiagram of the chest showed a rounded small shadow in the left infraclavicular region, which was thought to be an arrested Koch's lesion. Heart was normal in size. Urinalysis and routine blood investigations were normal, as was a 12-lead electrocardiogram. No acid-fast organisms were grown from the laryngeal swab.

Received January 8, 1968.

^ Present address: "Medical Sciences", Mayo Clinic, Rochester, Minnesota 55901, U.S.A.
Case 2. The eldest child of Case 1 was 20 at the time of examination. His parents thought he had always been of low intelligence. He gave a history of repeated attacks of painful red swelling over both feet since the age of 8. He was a well-developed boy of subnormal intelligence; slight non-pitting oedema was present over the feet; heart, lungs, and abdomen were normal. A loud systolic bruit was heard all over the head and along the carotid vessels. Optic fundi were normal and there was no neurological deficit. Thoracic $x$-ray examination and electrocardiogram were normal. A right-sided carotid angiogram revealed a large extracranial arteriovenous malformation over the postero-superior parietal region (Fig. 2). The superficial temporal and occipital branches of the external carotid artery were tortuous and dilated and fed the malformation. No dye was seen in the internal carotid artery or its branches.

Case 3. He was 16 years of age and had a history of attacks of fever and redness and swelling over the feet since the age of 8 . He was found to have lymphoedema over both feet. The heart was clinically enlarged, with

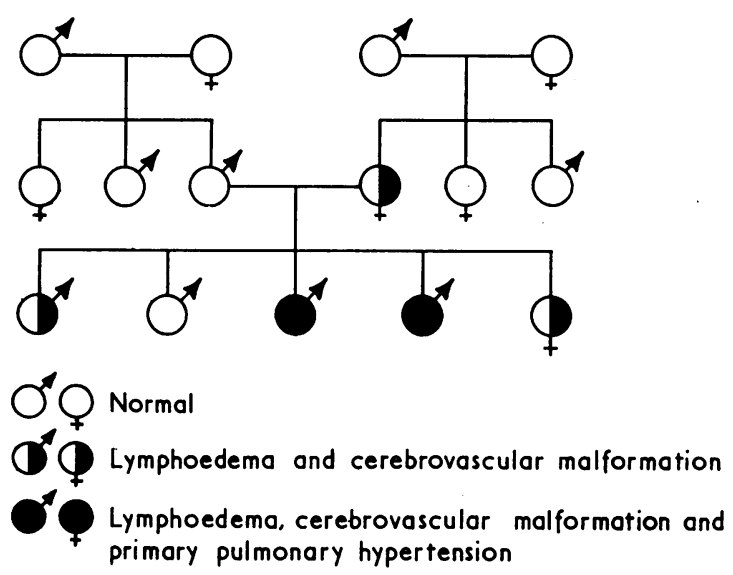

FIG. 1.-Family pedigree. Primary pulmonary hypertension, cerebrovascular malformation, and lymphoedema feet. 

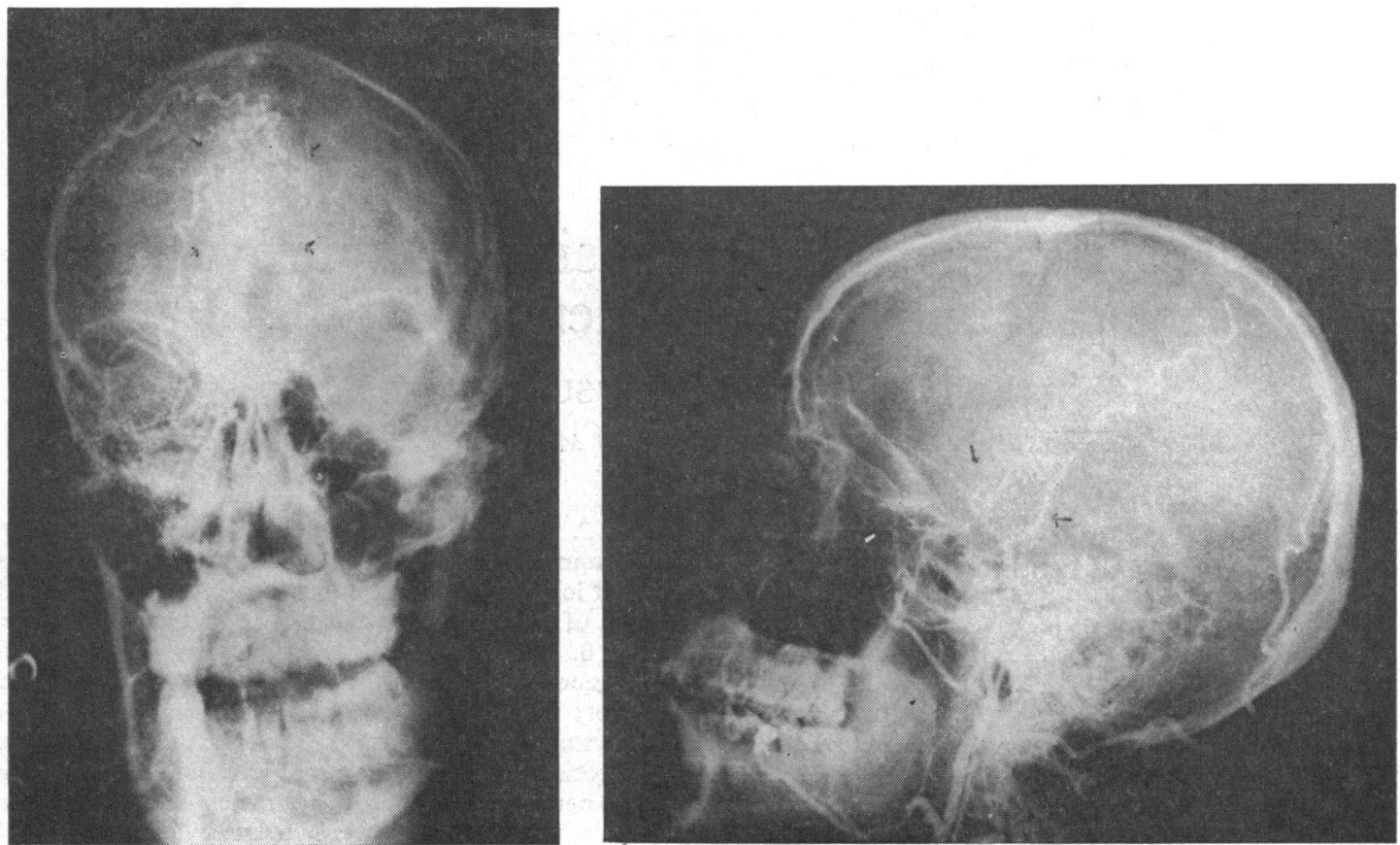

FIG. 2.-External carotid angiograms of Case 2, showing a large extracranial vascular malformation indicated out by arrows. Tortuous and dilated superficial temporal and occipital branches of the external carotid artery are seen in the lateral projection.

the apical impulse in the fifth space $2 \mathrm{~cm}$. outside the mid-clavicular line. There was a sustained left parasternal heave. A grade $2 / 6$ systolic murmur was heard in the pulmonary area and was conducted all over the chest. The pulmonary component of the second sound was accentuated, but the sound was normally split and moved with respiration. Lungs, abdomen, fundi, and central nervous system were normal. A loud systolic bruit was heard all over the head and over the carotid vessels in the neck. A skiagram of the chest (Fig. 3) revealed right-sided cardiac enlargement, dilated main pulmonary arteries, and constriction of the peripheral pulmonary arteries. The electrocardiogram (Fig. 4) showed severe right ventricular hypertrophy with strain.
Right-sided cardiac catheterization showed a pulmonary artery pressure of $115 / 35(60) \mathrm{mm}$. $\mathrm{Hg}$ and a pulmonary artery wedge pressure of $10 \mathrm{~mm} . \mathrm{Hg}$ (Table I). There was no evidence of an intracardiac shunt in the dye dilution curves nor in the blood gas analysis results.

Case 4. He was 14 at the time of examination. At the age of 1 year he had high fever followed by rightsided hemiplegia from which he partially recovered. He had also had attacks of red painful swelling of the feet and legs since early childhood. He looked fragile and chronically ill. There was lymphoedema over both feet. Residual right-sided hemiparesis was present, and the limbs of this side were smaller and less well developed

TABLE I

HAEMODYNAMIC DATA-PRIMARY PULMONARY HYPERTENSION

\begin{tabular}{|c|c|c|c|c|c|c|c|c|c|c|}
\hline $\begin{array}{l}\text { Case } \\
\text { No. }\end{array}$ & $\begin{array}{c}\text { Right } \\
\text { atrium } \\
(\mathbf{m m} . \mathbf{H g})\end{array}$ & $\begin{array}{c}\text { Right } \\
\text { ventricle } \\
\text { (mm. Hg) }\end{array}$ & $\begin{array}{l}\text { Pulmonary } \\
\text { artery } \\
(\mathbf{m m} . \mathbf{H g})\end{array}$ & $\begin{array}{c}\text { Pulmonary } \\
\text { artery } \\
\text { after } \\
\text { acetyl- } \\
\text { choline } \\
\text { (mm. Hg) }\end{array}$ & $\begin{array}{l}\text { Pulmonary } \\
\text { artery } \\
\text { wedge } \\
\text { (mm. Hg) }\end{array}$ & $\begin{array}{c}\text { Femoral } \\
\text { artery } \\
\text { (mm. Hg) }\end{array}$ & $\begin{array}{c}\text { Femoral } \\
\text { artery } \\
\text { oxygen } \\
\text { saturation } \\
(\%)\end{array}$ & $\begin{array}{c}\text { Cardiac } \\
\text { index } \\
(1 . / \mathrm{min} . / \\
\left.\mathrm{m}^{2} .\right)\end{array}$ & $\begin{array}{l}\text { Pulmonary } \\
\text { vascular } \\
\text { resistance } \\
\text { (units) }\end{array}$ & $\begin{array}{c}\text { Dye } \\
\text { dilution } \\
\text { curves }\end{array}$ \\
\hline $\begin{array}{l}3 \\
4\end{array}$ & $\begin{array}{c}2 \cdot 0 \\
(\text { mean) } \\
4 \cdot 0 \\
\text { (mean) }\end{array}$ & $\begin{array}{l}115 / 5 \\
180 / 5\end{array}$ & $\begin{array}{c}115 / 35 \\
(60) \\
186 / 50 \\
(108)\end{array}$ & - & $\begin{array}{c}10 \\
\text { (mean) } \\
11 \\
\text { (mean) }\end{array}$ & $\begin{array}{c}145 / 65 \\
(100) \\
188 / 68 \\
(110)\end{array}$ & $\begin{array}{l}95 \\
94\end{array}$ & $\begin{array}{l}3 \cdot 0 \\
5 \cdot 0\end{array}$ & $\begin{array}{l}16 \cdot 4 \\
14 \cdot 5\end{array}$ & $\begin{array}{l}\text { Normal } \\
\text { Normal }\end{array}$ \\
\hline
\end{tabular}




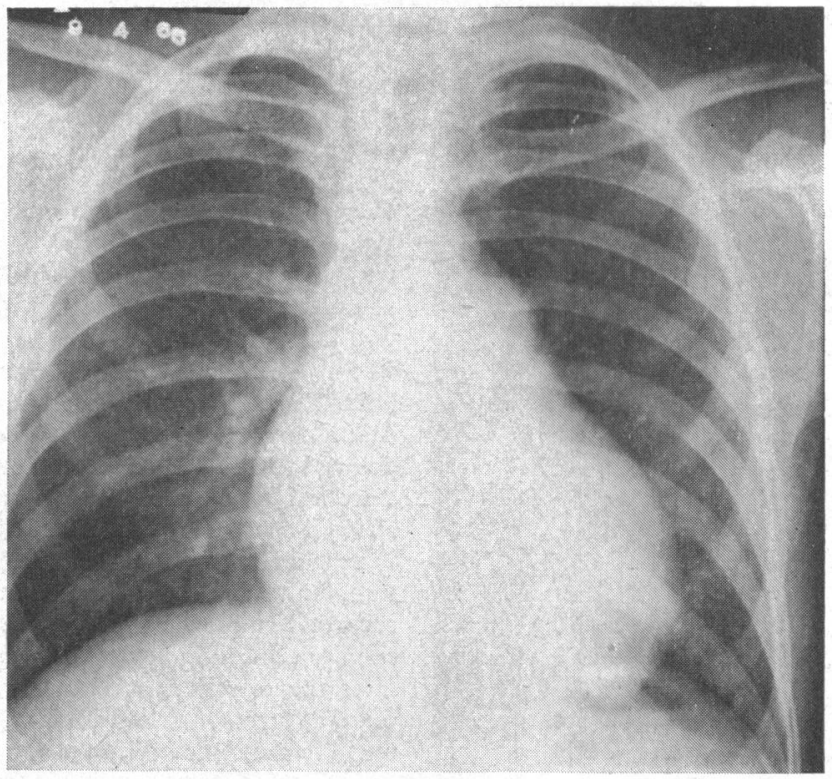

FIG. 3.-Postero-anterior chest $x$-ray of Case 3. The heart is enlarged and the main pulmonary arteries are dilated. There is constriction of peripheral pulmonary arteries.

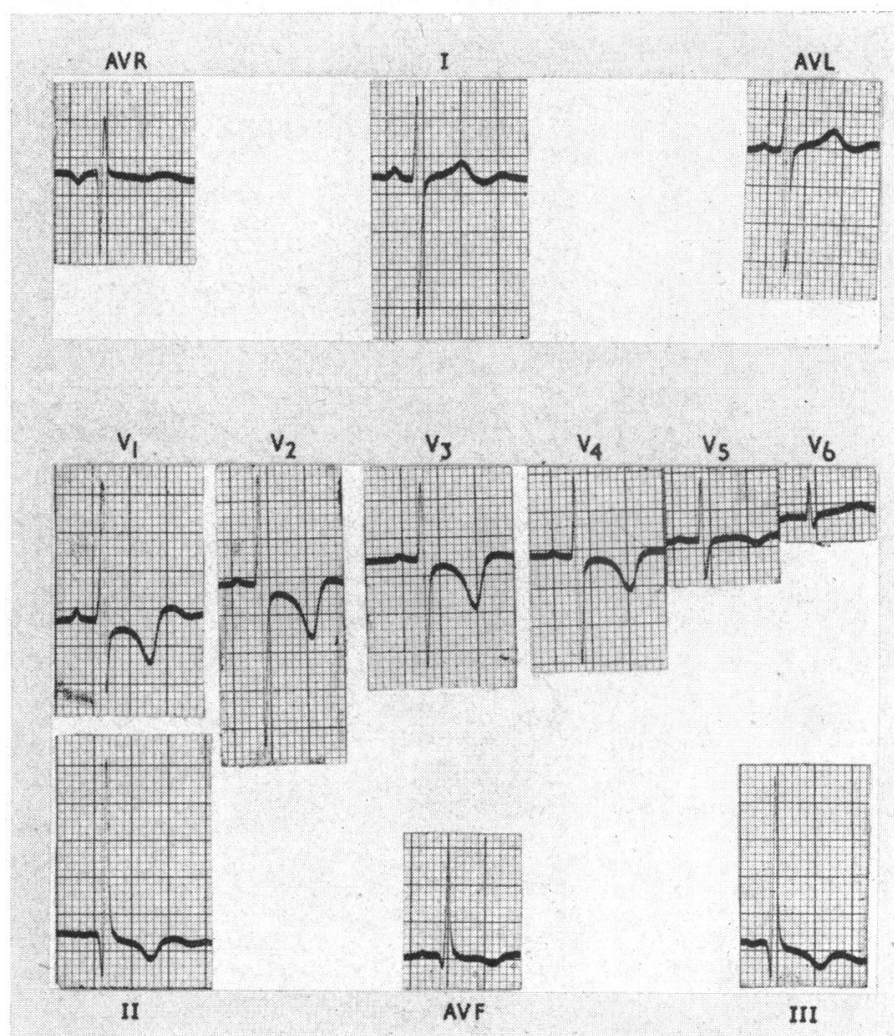

FIG. 4.-Electrocardiogram of Case 3 showing severe right ventricular hypertrophy with strain. 


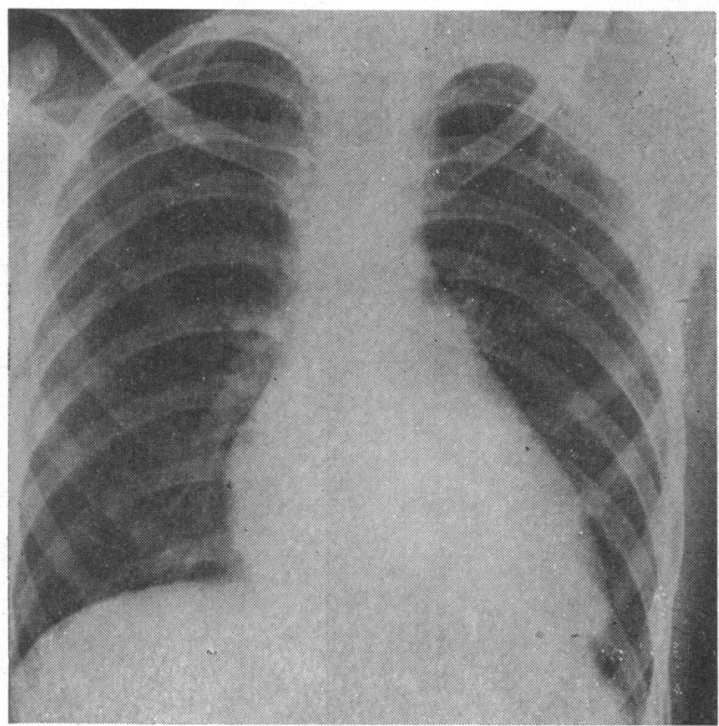

FIG. 5.-Postero-anterior chest $x$-ray of Case 4. The heart is enlarged, and the main pulmonary arteries are dilated. than their counterparts. Optic fundi were normal. A systolic bruit was heard over both temporo-parietal regions of the head. The heart was much enlarged, with the apical impulse in the fifth space at the anterior axillary line. A sustained impulse could be felt at the left parasternal region. A systolic thrill was palpable over both carotids and left subclavian artery. Grade 2/6 systolic murmur was heard at the pulmonary area and was also audible over the rest of the chest. The second sound was normally split and the pulmonary component was loud. The respiratory system was normal. There was no evidence of heart failure. Skiagrams of the chest (Fig. 5) showed a much enlarged heart and dilated main pulmonary arteries. The electrocardiogram (Fig. 6) showed severe right ventricular hypertrophy and strain. Cerebral angiography was unsuccessful. Skull $x$-ray showed no abnormality. Cardiac catheterization (Table I) revealed a pulmonary artery pressure of $186 / 50$ (108) $\mathrm{mm} . \mathrm{Hg}$, which was similar to the femoral artery pressure recorded simultaneously. There was a transient fall in the systolic pulmonary artery pressure by $50 \mathrm{~mm}$. $\mathrm{Hg}$ after the injection of $1 \mathrm{mg}$. acetylcholine into the pulmonary artery. The pulmonary artery wedge pressure was $11 \mathrm{~mm}$. Hg. There was no evidence of any intracardiac shunt.

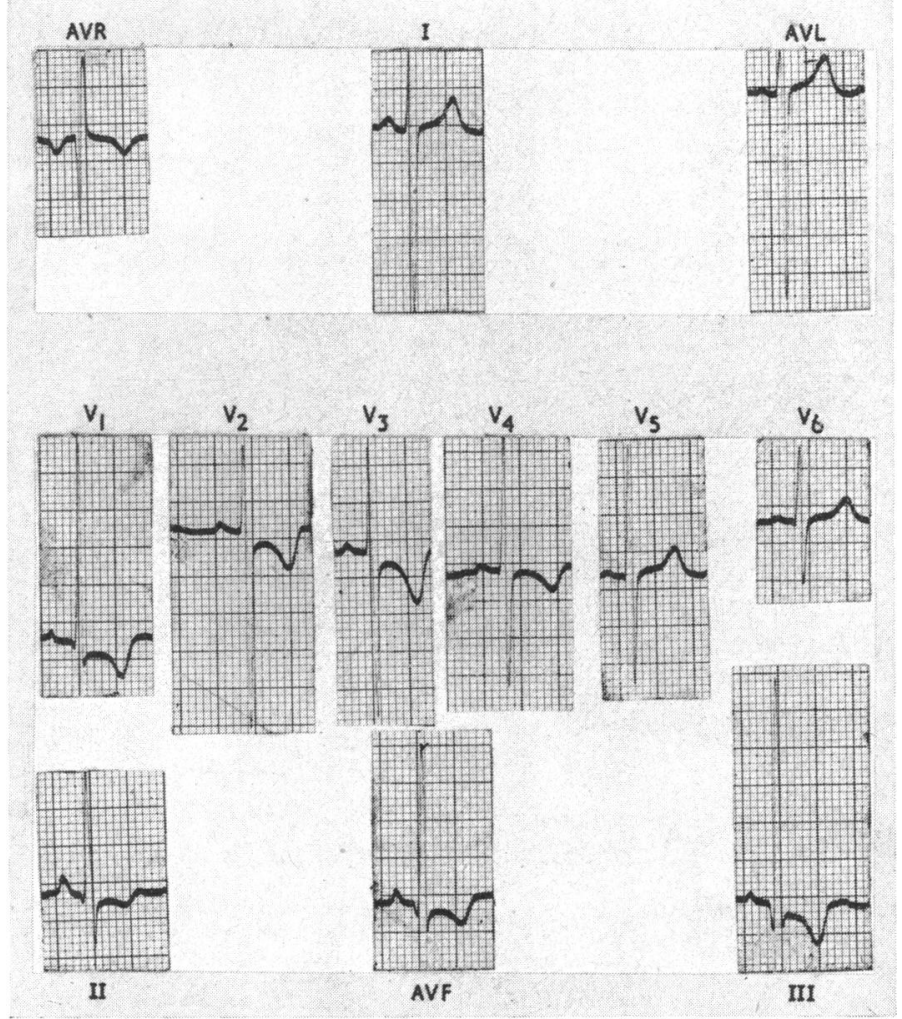

FIG. 6.-Electrocardiogram of Case 4, showing severe right ventricular hypertrophy with strain. 
Case 5. She was 11 years old, and asymptomatic. Clinical examination revealed lymphoedema over both feet. The cardiovascular system was normal. A systolic bruit was audible on both temporo-parietal regions of the head and along the carotids. Optic fundi and central nervous system, lungs, and abdomen were normal. Skiagram of chest and electrocardiogram were normal. Routine blood examination and urinalysis were normal.

A 17-year-old son was found to be completely normal. The father of these children suffered from a subclinical chronic lung disease, probably tuberculosis. This family hails from north-west India where filariasis is not endemic. Repeated blood films from the affected members were found to be negative for microfilaria.

\section{Discussion}

Within the past four decades enough data have been presented from various parts of the world to suggest genetic transmission of primary pulmonary hypertension from parent to offspring. Recently, Melmon and Braunwald (1963) have reported upon the occurrence of this form of hypertension in 5 relatives over 3 generations. Kingdon et al. (1966) have noticed the occurrence of genetic anticipation in their patients and also in the case of the mother and her two daughters described by Parry and Verel (1966). The mother in this family is still free from pulmonary hypertension.

The aetiology of primary pulmonary hypertension remains a mystery. Clarke et al. (1927) suggested an inborn imperfection in the development of the pulmonary arteries which they thought could be familial. Lange (1948) described a kindred of 186 members, 82 of 'whom were said to have cyanosis and dyspnoea. Coleman et al. (1959) suggested a defect in function which operated by an increase in the tone of the small muscular pulmonary arteries and which could be genetically transmitted. Boiteau and Libanoff (1963) thought that primary pulmonary hypertension could be the result of persistence of foetal pulmonary vascularity and rigidity of the arterial wall into adulthood. Congenital weakness of the arterial wall was also thought to be one of the causes of primary pulmonary hypertension (Evans, Short, and Bedford, 1957). Rosenberg (1964) considered that all instances of primary pulmonary hypertension were caused by multiple pulmonary embolization. Farrar (1963) brought forward the possible involvement of some hypersensitive immune mechanism. Kingdon et al. (1966) gave as a possibility the presence of a genetically determined hypercoagulable state, leading to thrombi formation and embolization of the pulmonary vascular tree.

Cases 3 and 4 suffer from a severe degree of primary pulmonary hypertension. In the families so far reported, female members have usually been predominantly involved (Table II). It is, therefore, curious that in this family the mother and the daughter have both escaped and that only two boys are involved. Cardiac catheterization showed the presence of severe pulmonary arterial and right ventricular hypertension. A fall in the pulmonary arterial pressure after injection of acetylcholine in Case 4 suggests that part of the pulmonary hypertension was due to active vascular constriction in the pulmonary bed. The absence of valvular defects or intracardiac shunts is proved by the catheterization data, dye dilution curves, and blood gas analysis. Venography, to exclude thrombosis of the inferior vena cava or its tributaries, was not performed.

Arteriovenous fistulae, if large, can produce overloading of the left side of the heart, leading to dilata-

TABLE II

SEX INCIDENCE IN FAMILIAL PRIMARY PULMONARY HYPERTENSION

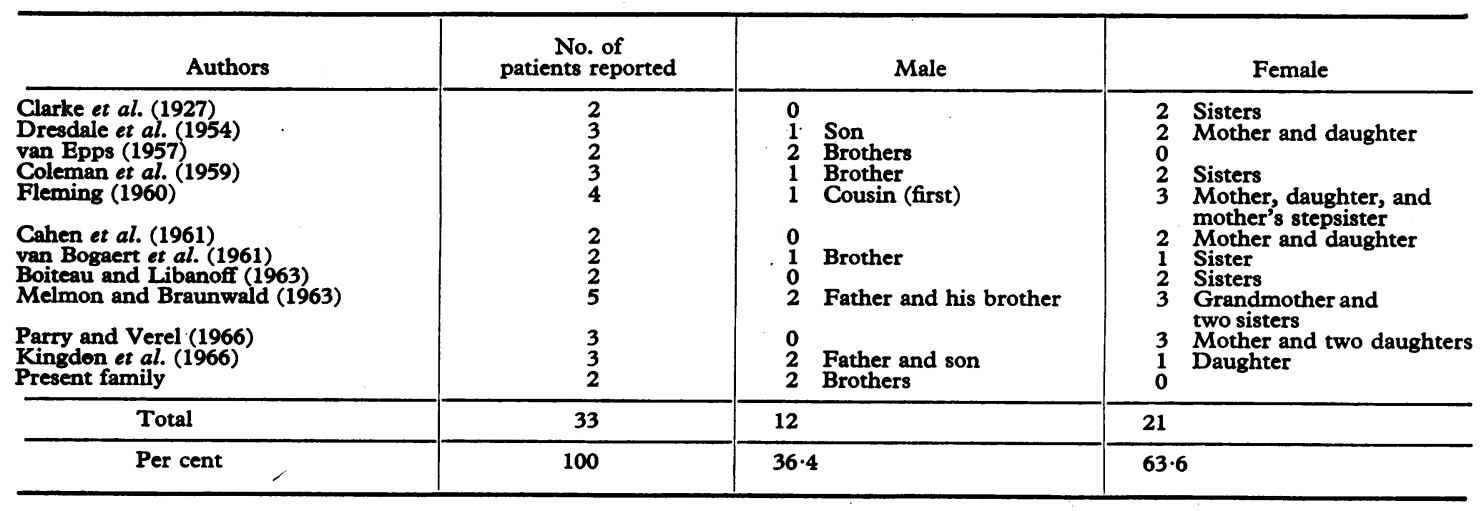


tion and hypertrophy and sometimes even to congestive heart failure in some acquired cases (Wood, 1956). But such a severe degree of pulmonary hypertension as is present in these two boys is not likely to occur from a hyperkinetic state which may be created by the fistula of an arteriovenous malformation. Besides, these two boys never had any symptoms of left heart embarrassment, and their reflected left atrial pressures were within normal limits. In the absence of any known aetiological. factor (Farrar, 1963; Berthrong and Cochran, 1955), pulmonary hypertension in these children can be assumed to be primary.

Five members of the present family suffer from lymphoedema of the feet and legs. The mother gives a history of two acute febrile episodes of painful red swelling of the feet and legs at the ages of 13 and 15 years, respectively. The affected children began getting such attacks at about the age of 8 years. The attacks occur without any rule or order, are often associated with injury on the lower limbs, and last for 2 to 6 days. In these respects the disease resembles Milroy's familial lymphoedema, as described by Hope and French (quoted by Milroy, 1928). Their patients also suffered from illnesses, such as feeble-mindedness and epilepsy. None of the patients had lymphoedema at birth. Meige in 1898 described 8 patients over 4 generations in whom onset of lymphoedema occurred near puberty. Esterly and McKusick (1959) have proposed that a primary mechanism in the production of familial lymphoedema could be defective contractility of the arterioles in the subcutaneous tissue.

The mother and the 4 children also suffer from an arteriovenous malformation. None of them had cutaneous or retinal angiomata. Carotid angiography of Case 2 confirmed the presence of a big extracranial vascular malformation in the posterosuperior parietal region. Though an intracranial arteriovenous malformation could not be demonstrated in this or other patients, there is a strong possibility of its existence in some or all of them. These cirsoid aneurysms are known to be associated with intracranial arteriovenous malformations. Familial occurrence of various types of cerebral angiomata, arteriovenous malformations, and cirsoid aneurysms has been described (Lindau, 1930). The arteriovenous malformations represent the persistence of embryonic arteriovenous shunts: 65 per cent of them occur over one cerebral hemisphere and are often associated with bruit audible over the skull. They consist of a mass of coiled, tortuous thin-walled blood vessels, often incorporating some brain tissue among the coils. The brain tissue is usually abnormal due to gliosis resulting from pressure or from dysgenesis (Pool and Potts, 1965). The tumours may erode the overlying bone or press on the underlying brain tissue, or project into one of the ventricles. Patients may suffer from pressure symptoms like headache or convulsions, and from systolic tinnitus. Sometimes there is haemorrhage due to rupture of the thin-walled vessels, producing paretic lesions or even death. Case 4, the younger boy, had an episode of hemiplegia in infancy, which may have been due to haemorrhage from the tumour.

In this family, we are faced with the unique combination of three diseases which are known to run in familes individually but which have no common aetiological grounds except that they involve tissues arising from mesoderm. The obvious question to be raised under the present circumstances is whether these three conditions form a triad that is inheritable and is a genetically determined maldevelopment. The association of lymphoedema of the feet and arteriovenous malformation in five members of the family over two generations and of primary pulmonary hypertension in two sibs cannot be said to have occurred by mere chance, especially when these three conditions are not common otherwise.

\section{SUMMARY}

A family of a mother and four of her five children has been described. The mother and the four children suffer from idiopathic lymphoedema of the feet and legs and from an arteriovenous malformation. Two of these children (brothers) suffer from severe pulmonary hypertension. These three diseases individually are known to run in families. Their occurrence together in most of the members of one family suggests inheritable mesodermal maldevelopment.

The authors are very grateful to Dr. M. L. Bhatia for help with the cardiac catheterization and to Dr. V. Virmani for cerebral angiography.

\section{REFERENCES}

Berthrong, M., and Cochran, T. H. (1955). Pathological findings in nine children with "primary" pulmonary hypertension. Bull. Johns Hopk. Hosp., 97, 69.

Boiteau, G. M., and Libanoff, A. J. (1963). Primary pulmonary hypertension: familial incidence. Angiology, 14, 260.

Cahen, P., Gonin, A., Froment, R., and Dalloz, C. (1961). Hypertension pulmonaire primitive chez la mère et la fille. Arch. Mal. Coeur, 54, 95.

Clarke, R. C., Coombs, C. F., Hadfield, G., and Todd, A. T. (1927). On certain abnormalities, congenital and acquired, of the pulmonary artery. Quart. F. Med., 21, 51 .

Coleman, P. N., Edmunds, A. W. B., and Tregillus, J. (1959). Primary pulmonary hypertension in three sibs. Brit.
Heart $\mathcal{F} ., 21,81$. 
Dresdale, D. T., Michtom, R. J., and Schultz, M. (1954). Recent studies in primary pulmonary hypertension including pharmacodynamic observations on pulmonary vascular resistance. Bull. N.Y. Acad. Med., 30, 195.

Esterly, J. R., and McKusick, V. A. (1959). Genetic and physiologic studies of Milroy's disease. Clin. Res., 7, 263.

Evans, W., Short, D. S., and Bedford, D. E. (1957). Solitary pulmonary hypertension. Brit. Heart f., 19, 93.

Farrar, J. F. (1963). Idiopathic pulmonary hypertension. Amer. Heart f., 66, 128.

Fleming, H. (1960). Primary pulmonary hypertension in eight patients including a mother and her daughter. Aust. Ann. Med., 9, 18.

Kingdon, H. S., Cohen, L. S., Roberts, W. C., and Braunwald, E. (1966). Familial occurrence of primary pulmonary hypertension. Arch. intern. Med., 118, 422.

Lange, F. (1948). Die essentielle Hypertonie der Lungenstrombahn und ihr familiäres Vorkomnen. Dtsch. med. Wschr., 73, 322.

Lindau, A. (1930). Discussion on vascular tumours of the brain and spinal cord. (Sargent, P., p. 370 . Russell, D., p. 383. Collins, E. T., p. 372. Rawling, L. B., p. 385. Cohen, H., p. 386.) Proc. roy. Soc. Med., 24, 363.
Meige, H. (1898). Dystrophie oedemateuse héréditaire. Presse méd., 6, 34

Melmon, K. L., and Braunwald, E. (1963). Familial pulmonary hypertension. New Engl. f. Med., 269, 770.

Milroy, W. F. (1928). Chronic hereditary edema. f. Amer. med. Ass., 91, 1172.

Parry W. R., and Verel, D. (1966). Familial primary pulmonary hypertension. Brit. Heart f., 28, 193.

Pool, J. L., and Potts, D. G. (1965). Aneurysms and arteriovenous anomalies of the brain. In Arteriovenous Malformations and Other Vascular Anomalies, pp. 326-373. Harper and Row, Hoeber Medical Division, New York.

Rosenberg, S. A. (1964). A study of the etiological basis of primary pulmonary hypertension. Amer. Heart $\mathcal{F}$., 68, 484.

van Bogaert, A., Wauters, J., Tosetti, R., and d'Heer, H. (1961). Hypertension pulmonaire primitive familiale. Arch Mal. Coeur, 54, 1185.

van Epps, E. F. (1957). Primary pulmonary hypertension in brothers. Amer. F. Roentgenol., 78, 471.

Wood, P. (1956). Diseases of the Heart and Circulation, 2nd ed., p. 909. Eyre and Spottiswoode, London. 